\title{
Effects of Communal Crises on Selected Crops Production Among Farmers in Langtang North Local Government Area of Plateau State, Nigeria
}

\author{
Kughur P. G. ", Daudu S., Iornenege G. M. \\ Department of Agricultural Extension \& Communication, University of Agriculture Makurdi, Makurdi, Nigeria
}

Email address:

gyandenkugh@gmail.com (Kughur P. G.)

${ }^{*}$ Corresponding author

\section{To cite this article:}

Kughur P. G., Daudu S., Iornenege G. M. Effects of Communal Crises on Selected Crops Production Among Farmers in Langtang North Local Government Area of Plateau State, Nigeria. International Journal of Education, Culture and Society. Vol. 2, No. 1, 2017 , pp. $33-37$. doi: $10.11648 /$ j.ijecs.20170201.15

Received: August 29, 2016; Accepted: January 7, 2017; Published: March 4, 2017

\begin{abstract}
The study investigated the effects of communal crises on selected crops production among farmers in Langtang North local Government Area of Plateau State, Nigeria. Multi-stage sampling technique was adopted; four local government areas were selected in each of the local government selected, four villages affected by communal crises were selected purposively. In two of the villages selected, 24 respondents each (people affected by communal crises) were selected and 25 respondents each were also selected randomly in the other two villages giving a total of 98 respondents. Primary data were collected through administration of structured questionnaire; data gathered were analyzed by descriptive statistics and correlation. The findings revealed that $38.8 \%$ communal crises were caused by religion, $43.9 \%$ communal crises leads to loss of lives, $87.8 \%$ used assorted types of guns during communal crises and there was significant reduction in quantity and value of money on crops produced before and after communal crises. The study recommends that government should implement white paper reports on communal crises and religious organizations should continually organize inter-religious group public enlightenment programmes to encourage peaceful co-existence among believers of different faiths.
\end{abstract}

Keywords: Effects, Communal Crises, Selected, Crop Production, Farmers

\section{Introduction}

Competition over scarce resources, particularly land and water, often causes or exacerbates communal conflict [1], [2]. Communal conflict involves groups with permanent or semipermanent armed militias but does not involve government forces. However, it can escalate to include government forces, as in the massacres in Darfur, Rwanda and Burundi. These conflicts have the potential to escalate to civil war when government is perceived to be supporting tacitly or otherwise, one communal group at the expense of the other [3]. In the process of utilising these scarce resources for the diverse, complex and competing socio-economic activities of the people, conflicts over access and management of these resources often arise. These conflicts significantly vary in dimension, process and the groups involved [4]. While some conflicts arise between similar resource users such as between one farming community and another, others occur between different resources users such as between pastoralists and farmers or between foresters and farmers. Similarly, conflicts my take different dimensions as some are non-volatile while others are volatile [5].

There is controversy about causes of conflict. A major cause of disagreement appears to be whether conflict is caused by economic or non-economic factors. Proponents of the economic argument contend that the propensity to indulge in conflict is higher for low-income or less-educated people [5], [6], [7]. The outcome of this argument is that poor economic conditions and a low quality of life can serve as a breeding ground for conflicts.

In contrast to the economic argument [8] argued that whether conflict is caused by economic or non-economic factors depend on the nature of conflict. Noting for instance, that terrorism is unrelated to economic opportunity, they conclude that the evidence of a connection between conflict 
and economics is highly elusive. [9] also gives primacy to non-economic factors in the explanation of conflict, pointing out that political leaders often encourage individuals and groups to engage in conflicts in order to promote their parochial interest.

In their explanation of the spate of conflicts in Africa, analysts have used economic and non-economic factors. One of the often cited non-economic factors is the concept of state failure, which has been blamed for conflict in Somalia, Rwanda, Liberia and Sierra-Leone [10]. According [11], a state is supposed to provide essential public goods such as law and order, defence, contract enforcement and infrastructure. In Africa, however some states provide very few of these goods. Indeed, many states are unable to exercise control over much of their territory, not to talk of providing order or public goods.

For centuries, most wars were fought for the possession of land and the average man everywhere lives in close association with the soils, fields, forests, fishing grounds that provided him with sustenance [12]. These conflicts over land occur because ownership or control of land is a sign of economic power and social standing. The issue of control over agricultural land and even pastoral resources is a major concern and there have been armed clashes between groups resulting in loss of human lives [13]. Furthermore, land tenure systems are changing at different paces, more or less profoundly and probably not in a single direction. Conflicts have social, political and cultural as well as legal dimensions. This puts serious demand on the societies' capability to resolve or manage conflicts [14].

The causes and types of conflicts vary from one period to another and from one area to another. In Nigeria today, we are witnessing several conflicts. Most of these conflicts have their roots either remotely or directly in the type of land policy in use. For example, the crises in Taraba, Benue and Nasarawa States, Osun State (Modakeke/Ife), Anambra State (Umuleri-Aguleri), Delta State (Ijaw/Itsekir) among others can be linked to the land acquisition. In all these crises, it is the common man that is the hardest hit. This kind of situation has serious security implication for the country in terms of national food supply and macro-economic performance in general. The most prominent of these conflicts arising out of resource utilisation and management has been pastoralistsfarmer conflicts. Farmer-farmer conflict, farmer conservationist conflict, pastoralists'-conservationists' conflicts and pastoralists-fishermen conflicts have been recorded as well [15]. Conflict not only occurs within use but also in administration and management, conflicts between government agencies (such as states and federal institutions) and the traditional institutions [5], [16].

The resultant increase in competition for arable land has often times led to serious manifestation of hostilities and social friction among the two user-groups in many parts of Nigeria. Conflicts have not only heightened the level of insecurity, but have also demonstrated high potential to exacerbate the food crisis in Nigeria and other affected countries due to loss of farmers' lives, animals, crops and valuable property [17]. For instance, the conflict in Darfur region of Sudan started as a resource based conflict between herdsmen and farmers before transforming into a full-blown war that has claimed over 200,000 lives and rendered over a million people homeless [18].

Losses from these conflicts are of far-reaching dimensions and implications on both sides. In a study carried out in Nigeria's Guinea savannah, within which is Kwara State, [19] reported that out of about 150 households interviewed, 22 reported loss of a whole farm of standing crops, 41 reported losses of livestock, while eight households from both sides reported loss of human lives. Other studies also indicated that stores, barns, residences and household items were destroyed in many of the violent clashes.

The failure of the government over the years to forge and implement a national theory of Nigerian citizenship leads to communal violence. A national theory of Nigerian citizenship is one which supports a generalised citizenry, where states are required to honour the national citizenship of so-called non-indigenes and where such citizens are allowed to own property in any part of the state, in which they reside, and to run for and hold office there after a reasonable period of residency. Yet some states in Nigeria have different rates of school fees between indigenes and settlers. The current situation whereby Nigerians are virtual foreigners in states where they are not considered indigenes is unfair; it also enshrines in us-versus-them psychology of separateness that is easily exploited by the country's many political warlords [20]. The entwining of religion and ethnicity in Nigeria is deep and dangerous. Of the three major ethnic groups, the Hausa-Fulani in the north is mostly Muslim, the Igbo and Yoruba in the south are mostly Christian (although there is a significant number of Yoruba Muslims). Given the regional domination of Nigerian politics at independence by these majority ethnic groups, many people especially the uneducated masses who are the foot soldiers of communal conflict and whose baleful neighbourhoods are its battlefields tend to see all southerners as Christians and all northerners as Muslims. In fact, there are many Muslims and Christians among southern and northern ethnic groups respectively [20].

There is also an economic reason Nigeria's poor burn their neighbourhoods and slaughter each other. Generally, the economy has failed to keep pace with the needs of the teeming population. The reasons include an inherited mismanaged and decaying economic system, perennial overdependence on oil, apathetic foreign investment, a bloated public sector and omnipresent corruption in high places. The resultant macroeconomic problems rain down hard on the poor in both urban and rural areas where most of the violence takes place. However, there are also communal conflicts motivated directly by struggles over economic resources such as farm and grazing lands [20].

\section{Materials and Methods}

The central location of Plateau State in Nigeria and its climatic conditions has blessed it to be conducive for the 
cultivation of a large variety of agricultural produce. The state has two dominant seasons; rainy and dry seasons. Rainfalls between April and October while the dry season starts from November to March. The availability of abundant land and low population density has made agricultural production an important part of the rural economy. Langtang North is one of the 17 Local Government Areas (LGAs) in Plateau State; the LGA is located in the Southern senatorial zone of Plateau State. It lies on longitude $10^{\circ} \mathrm{N}$ and latitude $10^{\circ} \mathrm{E}$. The LGA shares common boundaries with six (6) other LGAs namely: Kanke LGA to the north, Kanam LGA to the north east, Wase LGA to the east, Langtang South to the south, Shendam to the South-West and Mikang LGA to the west. It has a landmass of 11,980 square kilometres and a population of 142, 216 people [21].

The main occupation of the people is farming. The LGA is blessed with fertile land and the geographical features are hills and rocks. Taroh (a local tribe in the area) people make up $95 \%$ of the total population and are the dominant ethnic group. Other ethnic groups are Igbo, Yoruba, Ngas and Urobo who live in nucleated settlement of Kuffen and Bwarat. Crops cultivated includes; sorghum, maize, cassava, yam, rice, groundnuts, cowpea and cotton. They also engage in livestock and poultry farming. Multi-stage sampling technique was adopted. The population of the study comprised all the rural farmers in the area. Four districts were purposively selected because of intensity of communal conflicts in the area, they include: Bwarat, Gani, Gazum and Kuffen. In two of the four districts selected, 24 respondents each (people affected by communal crises) were selected and in the other two districts 25 respondents each were selected randomly, thus, a total of 98 respondents were used for the study. In two of the districts selected, 25 respondents were selected based on population of people in the districts. Data gathered were analyzed through descriptive and inferential statistics (correlation).

Model Specification:

$$
r=\frac{\sum(Y-\bar{Y})(X-\bar{X})}{\sqrt{\sum(Y-\bar{Y})^{2}} \sqrt{\sum(X-\bar{X})^{2}}}
$$

Where;

$$
\mathrm{r}=\text { correlation }
$$

$\mathrm{Y}=$ Selected crops produced before communal conflict

$\mathrm{X}=$ Selected crops produced after communal conflict

\section{Results and Discussion}

Table 1. Distribution of Respondents by Causes of Communal Crises.

\begin{tabular}{lll}
\hline Cause & Frequency & Percentage \\
\hline Religion & 38 & 38.8 \\
Pastoralists and farmers disagreement & 28 & 28.6 \\
Chieftaincy tussles & 19 & 19.4 \\
Political positions & 13 & 13.3 \\
Total & 98 & 100 \\
\hline
\end{tabular}

Results in Table 1 showed causes of communal conflicts: religion $38.8 \%$, pastoralists and farmers' disagreement $28.6 \%$, chieftaincy tussles $19.4 \%$ and political positions $13.3 \%$. Communal crises were caused by religion (38.8\%). This is because of the increasing employment of religion as a political weapon in the struggle for power, people preach in their places of worship drawing a distinction line between various religions. This has created a lot of disparity between Muslims and Christians. The result contradicts [22] who reported that scramble for the scare economic resource of land is one of the major causes of communal dispute in Cross River State, Nigeria. The result corroborates [23] who endorsed that politicians have urged their followers to vote along religious lines, Muslims are told to vote Muslims and Christians to vote Christians during elections.

Table 2. Distribution of Respondents Based on Effects of Communal Crises.

\begin{tabular}{lll}
\hline Effect & Frequency & Percentage \\
\hline Loss of lives & 43 & 43.9 \\
Destruction of property & 30 & 30.6 \\
Cannot access my farm land & 16 & 16.3 \\
Disruption of farm & 9 & 9.2 \\
Total & 98 & 100 \\
\hline
\end{tabular}

Results in Table 2 indicated that loss of lives $43.9 \%$, destruction of property $30.6 \%$, cannot access my farm land $16.3 \%$ and disruption of farm $9.2 \%$. Loss of lives during communal crises $(43.9 \%)$, this is an indication that most of the areas affected were taken unaware or were not prepared for any crises and do not have any weapons to protect themselves. During communal crises people affected lost many things including lives. Killing of people during communal crises is done to weaken the opponent during crises. This confirms [24] who reported that attacks on villages during communal conflict leads to death of many people. The finding also agrees with [18] who also reported loss of human lives during conflict and also stores, barns, residences and household items among others are usually destroyed in many of the violent clashes in Nigeria. Similarly, [22] reported that communal conflicts have the capacity to severely constrain development endeavour by destroying infrastructure, interrupting the production process and diverting resources away from productive uses to other uses like buying of weapons by the warring communities among others.

Table 3. Distribution of Respondents by Weapons used During Communal Crises.

\begin{tabular}{lll}
\hline Weapon & Frequency & Percentage \\
\hline Guns (G3, AK47 \& Pistol) & 86 & 87.8 \\
Bow and arrows & 69 & 70.4 \\
Knives & 41 & 41.8 \\
Cutlasses & 31 & 31.6 \\
Machetes & 25 & 25.5 \\
Sticks & 21 & 21.4 \\
Spears & 2 & 2.0 \\
\hline
\end{tabular}

*Multiple responses*

Results in Table 3 revealed weapons used; guns $87.8 \%$, bow and arrows $70.4 \%$, knives $41.8 \%$, cutlasses $31.8 \%$, 
machetes $25.5 \%$, sticks $21.4 \%$ and spears $2.0 \%$. Majority $(87.8 \%)$ used guns during the conflict. This is an indication that most people have arms and ammunitions in their possession. The possession of arms and ammunitions is very high in places where there is constant communal conflict; most people who possess some of these arms and ammunitions feel is for protection of their live and property. The possession of arms and ammunitions is a serious threat to the security of people within the vicinity in particular and the state in general. This result is similar to [25] who endorsed that small arms and light weapons are often the most common weapons used during communal conflict in Nigeria.

Table 4. Descriptive Statistics of Quantity (Kg) and Value (\#) of Crops Destroyed before and after Communal Crises.

\begin{tabular}{lllll}
\hline Variables & Mean & $\begin{array}{l}\text { Std. } \\
\text { Deviation }\end{array}$ & Minimum & Maximum \\
\hline Qty (kg) before & & & & \\
Cowpea & 190.3064 & 247.63398 & 0.00 & 1500.00 \\
Groundnut & 763.4694 & 978.883 & 0.00 & 8000.00 \\
Maize & 956.84 & 1226.59 & 0.00 & 7000.00 \\
Rice & 994.2857 & 1149.25 & 0.00 & 8000.00 \\
Sorghum & 585.31 & 941.724 & 0.00 & 6000.00 \\
Qty (kg) after & & & & \\
Cowpea & 63.5714 & 104.064 & 0.00 & 500.00 \\
Groundnuts & 161.22 & 198.387 & 0.00 & 1000.00 \\
Maize & 230.31 & 303.653 & 0.00 & 2000.00 \\
Rice & 357.4490 & 1231.8 & 0.00 & 12000.00 \\
Sorghum & 139.29 & 231.785 & 0.00 & 1500.00 \\
Values (\#) before & & & & \\
Cowpea & 36204 & 46716.1 & 0.00 & $300,000.00$ \\
Groundnuts & 67622 & 62917.5 & 0.00 & $300,000.00$ \\
Maize & 102880 & 126461 & 0.00 & $600,000.00$ \\
Rice & 79724 & 92010.6 & 0.00 & $640,000.00$ \\
Sorghum & 51033 & 76676.5 & 0.00 & $400,000.00$ \\
Values ( ( after & & & & \\
Cowpea & 12951 & 21040.9 & 0.00 & 100,000 \\
Groundnuts & 16969 & 21570.1 & 0.00 & 100,000 \\
Maize & 26306 & 35138.4 & 0.00 & 240,000 \\
Rice & 19959.1837 & 27173.71318 & 0.00 & $160,000.00$ \\
Sorghum & 13500 & 23059 & 0.00 & 150,000 \\
\hline
\end{tabular}

Results in Table 4 showed that cowpea, groundnuts, maize, rice and sorghum have higher quantities and value in Naira (N) produced before the conflict, however smaller quantities and value in Naira (N) were obtained after the conflict. This is an indication that whenever there is conflict crop production always goes down because of lack of peace. During communal conflicts farmers are scared of visiting their farm for the fear of being killed as a result of the conflict; this significantly reduce the quantity of crops produced during the period. This confirms [26] who reported that farmers also experienced low productivity from crops grown since they no longer employ all the necessary farm practices for fear of being caught by the enemy side, stealing of farm produce, rancour, enmity, fear and suspicious are all effects of communal conflicts. [18] also reported that out of about 150 households interviewed, 22 reported loss of a whole farm of standing crops among others.
Table 5. Descriptive Characteristics of Quantity (Kg) and Value (A) of Crops before and after Communal Crises.

\begin{tabular}{|c|c|c|}
\hline Variable & Before & After \\
\hline Total Quantity (kg) & Freq (percentage) & Freq (percentage) \\
\hline 0 & 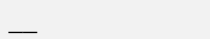 & $23(23.5)$ \\
\hline $1-500$ & $1(1.0)$ & $18(18.4)$ \\
\hline $501-1000$ & $10(10.2)$ & $28(28.6)$ \\
\hline $10001-5000$ & $67(68.4)$ & $28(28.6)$ \\
\hline $50001-500000$ & $20(20.4)$ & $1(1.0)$ \\
\hline Total Values ( & Freq (percentage) & Freq (percentage) \\
\hline 0 & - & $23(23.0)$ \\
\hline $50001-100000$ & $6(6.1)$ & $13(13.3)$ \\
\hline $100001-500000$ & $75(76.5)$ & $30(30.6)$ \\
\hline $500001-1000000$ & $14(14.3)$ & $3(3.6)$ \\
\hline $1 m-2 m$ & $3(3.1)$ & $1(1.0)$. \\
\hline
\end{tabular}

Results in Table 5 showed quantity of crops produced before and after the conflicts; cowpea, groundnuts, maize, rice and sorghum $(\mathrm{Kg})$ were produced in higher quantities before the communal crises and their corresponding monetary value in Naira ( $\#)$ were also higher or encouraging but after the crises the total quantity $(\mathrm{kg})$ of the selected crops produced and their respective values in Naira ( were not up to the quantity and values produced before the conflict. Comparing the quantity of output and the value in Naira $(\mathbb{N})$ before and after the conflict, this indicates that there were significant differences in quantity of crops produced before and after conflict. This is because many farmers did not go to their farm for the fear of been attacked. The finding corroborates [27] who reported that there were always differences in food production between war and peaceful years and their contribution to agricultural production. Similarly, [28] reported that communal conflict is one of the enemies of communal development and the problem is more complicated when villagers displaced by communal crises move to other areas for refuge. The finding is similar to [29] who asserted that production of crops and rearing of livestock is the main economic activity of the people in Nigeria. Therefore communal conflicts have serious implication on food production system.

\section{Conclusion and Recommendations}

Conflict is number one enemy of development as no place could develop during chaos; conflicts in the study area have destroyed communal relationships which have existed for many years. Most of the conflicts in the study area started as a result of religion, the warring factions used different arms and ammunitions which led to the destruction of lives and property worth millions of Naira. There were significant differences in quantity of crops produced and its corresponding value in Naira ( before and after communal conflicts. It is recommended that government should implement white paper reports on communal conflicts and religious organizations should organize public enlightenment programmes on the need for peaceful co-existence between believers of different faiths. 


\section{References}

[1] Homer-Dixon, T. (1999). Environment, Scarcity, and Violence. Princeton, Princeton University Press.

[2] Ban, K. 2007. A Climate Culprit in Darfur. Washington Post, 16 June.

[3] Kahl, C. 2006. States, Scarcity, and Civil Strife in the Developing World. Princeton, Princeton.

[4] Famoriyo, S. (1983). Impact of Land Tenure on Agricultural Production in Nigeria. Paper presented at the Second World Congress on Land Policy, Harvard Law School, Cambridge, Massachusetts, June 1.

[5] Ehrlich, I. (1975). Participation in illegitimate activities: A Theoretical and Empirical Investment. Journal of Political Economy, 81 (3) 521-522.

[6] Freeman, R. (1996). Why so many young American Men Commit Crimes do and what might we do about it. Journal of Economic Perspectives, 10 (1) 25-27.

[7] Piehl, A. M. (1998). Economic Conditions, work and crime in Michael (ed). Handbook on Crime and Punishment, Oxford. Oxford University Press.

[8] Krueger, A. B. and Maleckova, J. (2003). Education, Poverty and Terrorism: Is there a causal connection? Journal of Economics Perspectives. 17 (4).

[9] Kughur, P. G. and Umar, B. F. (2014). Communal Conflicts and Rural Livelihood in Benue State, Nigeria. International Journal of Development Studies, (9) 8. Centre for the Promotion of International Relation, Studies \& Development (CIRSD). 37-38.

[10] Herbst, J. T. (2002). States and Power in Africa; Comparative Lessons in Authority and Control, Princeton University Press.

[11] Robinson, J. (2002). States and Power in Africa. Journal of Economic Literature. Vol. XI.

[12] Barlowe, B. (1978). Land Resource Economics: The Economic of Real Estate. Prentice-Hall, New Jersey, P. 55.

[13] Famoriyo, S. (1984). Data Needs in Agricultural Land Use in Nigeria. Paper presented at the ARMTI Seminar on Record Keeping and Agro-Statistics Data Bank in Nigeria. Ilorin 23rd -25 th April.

[14] Famoriyo, S. (1987). Acquisition of Land and Compensation in Nigeria. In: Mortimore (ed.) Perspective on Land Administration in Northern Nigeria. Bayero University, Kano.

[15] Adisa, R. S. and Adekunle, O. A. (2010). Farmer-Herdsmen Conflicts: A Factor Analysis of Socio-economic Conflict Variables among Arable Crop Farmers in North Central Nigeria. J Hum. Ecol, 30 (1) 7-9 Kamla-Raj, India.

[16] Gefu, J. O. (2003). Land Tenure Systems in Nigeria. Land net, Nigeria, pp. 9-11.

[17] Cotula L, T. C, and Hesse, C. (2004). Land Tenure and Administration in Africa: Lesson of Experience and Emerging Issues, IIED. Retrieved on Oct. 102005 from http://www.iies.org/drylands/pubs/documents/ LT-cotula.pdf.

[18] FEWS-NET (2005). Resource Based Conflict and Food Security. Available at http://www.fews.net/. Accessed on 13/9/2006.

[19] Fiki, C. and Lee, B. (2004). Conflict Generation, Conflict Management and Self-organizing Capabilities in Droughtprone Rural Communities in North-eastern Nigeria: A case study. Journal of Social Development in Africa, 19 (2): 35-37.

[20] Onwudiwe, E. (2004). Communal Violence and the Future of Nigeria. Global Dialogue Vol. 6.

[21] NPC, (2006) National Population Commission, available on www. Population.gov.ng/ Retrieved $7^{\text {th }}$ September, 2016. Number 3-4 summer/Autumn

[22] Oji, R. O., Eme, O. I. and Nwoba, H. A. (2015). Human cost of communal conflicts in Nigeria: a case of Ezillo and EzzaEzillo conflicts of Ebonyi State, (2008-2010). Arabian Journal of Business and Management Review (OMAN Chapter) Vol. 4, No. 6; January.

[23] Falola, T. (1998). Violence in Nigeria: The Crisis of Religious Politics and Seccilar Ideologies. New York, University of Rochester Press. 21p.

[24] Spelten, A. (1995). The impact of ethnic conflict on food supply situation in Africa, Agriculture and Rural Development, 2 (2) University Press, 68p.

[25] Ikpeme, N. J. (2013). Small arms proliferation and its impact on communal conflict in Cross River State of Nigeria._Journal of Sociology. 21 (3) 18p.

[26] Chikaire, J., Atala, T. K., Akpoko, J. G. and Nnadi F. N (2011). Factors Influencing Agricultural Land-Use Conflicts in Ohaji Area of Imo State, Nigeria. www.sciencepub.net/report.

[27] Uyang, F. A., Nwagbara, E. N., Undelikwo, V. A. and Eneji, R. I. (2013). Communal Land Conflict and Food Security in Obudu Local Government Area of Cross River State, Nigeria. Advances in Anthropology. Vol. 3, No. 4, 193-194.

[28] Messer, E, Cohen, m. and Marchione, T. (2001). Conflict: A cause and effect of hunger. Agricultural and rural development, 8 (2): $67 \mathrm{p}$.

[29] Sambe, N., Avanger, M. Y. and Alakali. T. T. (2013). Communal Violence and Food Security in Africa. Journal Of Humanities And Social Science (IOSR-JHSS) Volume 9, Issue 3 (Mar.-Apr.). 